\title{
A Katonai Nemzetbiztonsági Szolgálat szakmai fejlődésének legfontosabb sajátosságai az elmúlt években²
}

\author{
The Most Important Features of the Professional Development \\ of the Military National Security Service in the Recent Years
}

Szakmai írásomban igyekszem összefoglalni a Katonai Nemzetbiztonsági Szolgálat megalakulása óta eltelt éveket, tekintettel az integrációt közvetlenül megelőző időszakra is. Áttekintem a jogszabályi környezet változásának szervezetre gyakorolt hatásait, a szervezeti átalakitásokat, a szervezetfejlesztés útját, az új biztonságpolitikai, nemzetbiztonsági és egyéb sajátságos szempontok megjelenését és hatásait, valamint a müveleti és müvelettámogató szakterületek munkáját leginkább befolyásoló döntéseket. Végezetül rávilágítanék néhány jelenleg is meghatározó feladatkörre, illetve néhány elvégzett szervezetmodernizációs feladatra. Mindezt annak érdekében, hogy az olvasó képet kaphasson egy a katonai nemzetbiztonsági tevékenységet hivatásszerüen gyakorló, modern nemzetbiztonsági szolgálatról.

Kulcsszavak: nemzetbiztonság, katonai nemzetbiztonság, Katonai Felderítő Hivatal, Katonai Biztonsági Hivatal, Katonai Nemzetbiztonsági Szolgálat

In my professional writing I strive to conclude the developments of the years since the foundation of the Military National Security Service, taking also into consideration the period before the integration. I review the effects of the changes of the legal environment on the organisation, the different reorganisations, the ways of system-development, the appearances of the new security policy, national security and other factors, as well as the decisions that affected most significantly the operational and operations support areas. At the end, I put some key work areas in the limelight, as well as some systems modernisation tasks executed. All these in order

Dr. Kenedli Tamás, hadtudományok doktora (PhD). ORCID-azonosító: 0000-0001-6720-716X Készült a KENEDLI-KIS-BENEDEK-SZABó (2016) könyvfejezet felhasználásával. 
to help the reader understand how a modern national security service is executing its legal tasks and duties.

Keywords: National Security, Military National Security, Military Reconnaissance Office, Military Security Office, Military National Security Service

\section{Bevezető}

Az önálló magyar katonai nemzetbiztonság 2018-ban ünnepelte fennállásának 100. évfordulóját. Amelyről a Katonai Nemzetbiztonsági Szolgálat (a továbbiakban: KNBSZ) különféle rendezvények keretében emlékezett meg, és kiadványokban dolgozta fel történelmének legfontosabb időszakait. Utóbbiak közül két kötetet mindenképp meg kell említeni: egyrészt a Válogatás a Magyar Katonai Felderítés és hírszerzés történetéből, másrészt A magyar katonai elhárítás története 1918-2018 címú múveket, amelyek a korábbi szervezetek tevékenységébe engedtek korlátozott betekintést. Megismertette az olvasóval, hogy az elődeink által folyamatosan épített, átalakításokon, strukturális és szakmai fejlesztéseken átesett szervezet miként nyerte el mai formáját. Jelenlegi írás a KNBSZ fejlődésének elmúlt nyolc évében megfigyelt változásait, azok tapasztalatait mutatja be közjogi, szervezetfejlesztési és szakmai oldalról, egyúttal igyekszik rámutatni azokra az intézkedésekre, amelyek segítették a szervezet folyamatos megújulását. Azonban ahhoz, hogy megfelelő kiindulópontot tudjunk képezni, mindenképp szükséges néhány gondolatot leírnunk a jogelőd szervezetek rendszerváltozást követő és egészen a 2011-ig tartó múködésének időszakáról.

A rendszerváltozást követő kezdeti időszakban a katonai felderítés/hírszerzés tevékenységében lényeges változások következtek be. ${ }^{3}$ A Minisztertanács határozata ${ }^{4}$ alapján, a Magyar Honvédség parancsnoka 019/1990. sz. parancsában, 1990. február 14-i hatállyal (az MHVK 2. Csoportfőnökség és Közvetlen Szervei jogutódjaként) megparancsolta a Magyar Honvédség Vezérkara Katonai Felderítő Hivatal létrehozását, amely mint nemzetbiztonsági szolgálat a Magyar Honvédség (a Honvéd Vezérkar) szervezetében végezte feladatait.

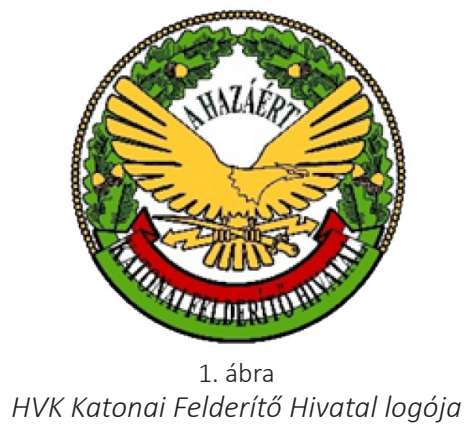


1995-ben a nemzetbiztonsági szolgálatokról szóló 1995. évi CXXV. törvény (a továbbiakban: Nbtv.) elfogadásával a HVK Katonai Felderítő Hivatal a vezérkar alárendeltségéből kikerült és a Magyar Köztársaság Katonai Felderítő Hivatala (a továbbiakban: MK KFH) néven, országos hatáskörü, önálló költségvetéssel rendelkező katonai nemzetbiztonsági szolgálatként, a honvédelmi miniszter közvetlen alárendeltségében folytatta tovább tevékenységét. A hivatal rendeltetésszerű feladatai voltak az $\mathrm{MH}$ ezen belül a Honvéd Vezérkar részére hadászati felderítési feladatok végrehajtása, a Magyar Köztársaság honvédelmi érdekeinek érvényesítését szolgáló kormányzati tevékenység segítése bizalmas információk megszerzése, elemzése és értékelése útján, valamint a hadmúveleti és harcászati felderítés szakirányítása az MH parancsnoksága szerveivel együttmúködve.

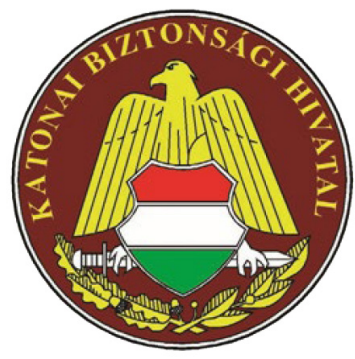

2. ábra

MK Katonai Biztonsági Hivatal logója

A Magyar Köztársaság Katonai Biztonsági Hivatal (a továbbiakban: MK KBH) a hazai nemzetbiztonsági rendszer szerves részeként, 1990. február 14. és 2011. december 31. között látta el a katonai elhárítás feladatait. A Magyar Honvédségen belül múködő szervként jött létre, munkatársai a fegyveres erők, azon belül a Magyar Honvédség állományába tartoztak. Az MK KBH-t a Magyar Köztársaság katonai biztonságának fenntartásában közremúködő, a HM és az $\mathrm{MH}$ biztonságáért felelős ${ }^{5}$ kémelhárító és alkotmányvédelmi szolgálatként lehetett definiálni.

Az MK KBH és az MK KFH integrációját megelőző két évben megújult a honvédelem rendszerét övező teljes jogszabályi háttér: az Alaptörvény vonatkozó részei, a honvédelmi törvény a szükséges végrehajtási utasításokkal, továbbá ehhez is illeszkedve az Nbtv. is új elemekkel egészült ki. Utóbbiból a legfontosabb momentum a KNBSZ nevesítése a nemzetbiztonsági szolgálatok között. ${ }^{6}$ 


\section{Az integráció időszaka (2011-2012)}

A KNBSZ megalakulását megelőzően számos előkészítő tevékenység történt a sikeres integráció megvalósítása érdekében. A katonai nemzetbiztonsági szolgálatok irányításáért felelős miniszter 2011-ben a költségvetési forrásokkal történő takarékosabb gazdálkodás megvalósítása érdekében, a szervezeti és létszám-racionalizálás mellett döntött ${ }^{7}$ és utasítást adott egy a költségvetési források takarékosabb felhasználását biztosító szervezeti felépítés kialakítására. Az elgondolás szerint egy „a katonai felderítő és elhárító tevékenység egységes ellátását, vezetését és koordinációját biztosító, a szakterületeken a hatékonyabb feladatellátást, valamint a költségvetési források takarékosabb felhasználását biztosító egységes szervezet és szervezeti felépítés"8 kialakítása vált szükségessé. Az Országgyűlés által megtárgyalt törvényjavaslatban ugyancsak visszaköszön a gazdaságosabb és hatékonyabb múködés biztosításának igénye: „A katonai nemzetbiztonsági szolgálatok hatáskörébe utalt feladatokat jelenleg két önálló szervezet, egyrészt a Katonai Felderítő Hivatal, másrészt a Katonai Biztonsági Hivatal látja el. Az említett szervek a jelenleginél gazdaságosabb, illetve hatékonyabb feladatellátásának biztosítása érdekében a két testület egyetlen szervezetté - KNBSZ - történő integrálásáról született döntés, amelynek végrehajtása az érintett jogszabályok egyidejü módosítását igényelte."9

Az integráció két ütemben zajlott le. Az első ütem 2011. augusztus-november között, az alábbi célkitűzések megjelölésével:

- a gyorsabb információáramlás feltételeinek, az erőforrások hatékonyabb felhasználásának kialakítása;

- a párhuzamosságok kiküszöbölése az eredményesebb múveleti munka elérése érdekében;

- a hatékonyabb védelem biztosítása a hadmúveleti területen feladatokat ellátó magyar kontingensek számára;

- a támogató rendszerek egységesítése, illetve kevesebb objektum üzemeltetése, a költségvetési kiadások csökkentése.

Az átalakítás során felülvizsgálták az alaptevékenységet támogató funkciókat, az azokat ellátó szervezeti egységeket, a bürokráciacsökkentés lehetőségeit. Ehhez kapcsolódva már az integráció első ütemében a vezetési szintek és a rendszeresített munkakörök számának csökkentése szerepelt a célkitǔzések között (a tervek szerint 217 beosztás és munkakör megszüntetése $\left.{ }^{10}\right)$.

A Nbtv. 2011. novemberi módosításának eredményeként megszületett a végleges döntés. A KBH 2011. december 31-jével megszűnt, jogutódként az átalakuló MK KFH vette át a feladatait. A KFH 2011. december 1-31. között új, de ideiglenes állománytábla alapján működött - december 1-jétől új főigazgató irányításával - és felkészült az átalakulásra, a feladatok jogutódkénti átvételére. Lényeges momentum volt, hogy

116/2011. (X. 21.) HM utasítás. Hatály: 2011. X. 22. - 2011. XII. 2.

128/2011. (XII. 2.) HM utasítás, 2. § (1) bekezdés, Hatály: 2011. XII. 3. - 2011. XII. 3.

T/4816. számú törvényjavaslat.

116/2011. (X. 21.) HM utasítás 3. § a) b) pont. Hatály: 2011. X. 22. - 2011. XII. 2. 
a meghatározott létszámcsökkentéseket még az eredeti szervezetek hajtották végre (illetve indították el a személyügyi eljárásokat).

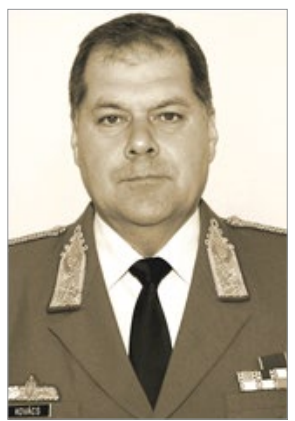

3. ábra

Kovács József altábornagy, főigazgató, 2011-2018

Forrás: BÉRES et al. 2018, 419.

A szervezési feladatok teljesítése érdekében fontos momentum volt, hogy a Magyarország 2012. évi költségvetéséről szóló törvényt már 2011. októberében megszavazta az Országgyúlés. Az átalakítás folyamatához mindez azért fontos információ, mivel a MK KFH és a MK KBH a Honvédelmi Minisztérium fejezetén belül önálló címként/ alcímként szerepel a költségvetési törvényben, tehát adottá vált, hogy a 2012. évi alaprendeltetés szerinti és átszervezéshez kötődő feladatokat a már jóváhagyott költségvetések terhére valósították meg. Természetesen az éves költségvetés októberben semmilyen plusz költségnemet nem tartalmazhatott az átalakításra vonatkozóan, hiszen arról csak egy hónappal később született meg a végleges döntés.

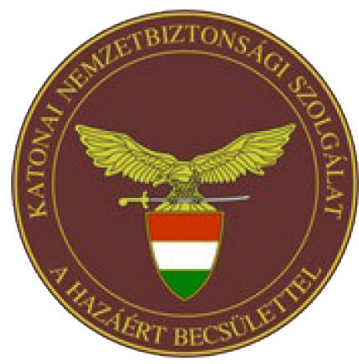

4. ábra

Katonai Nemzetbiztonsági Szolgálat logója 
Az MK KFH és az MK KBH integrációjával 2012. január 1-jén megalakult a KNBSZ. Az új szervezet létrejöttéhez elengedhetetlen szervezeti integráció során az MK KBH mint önálló költségvetési szerv megszűnt, a KNBSZ szervezetébe történő beolvadással,11 a KFH pedig névváltozását követően KNBSZ néven jogutódlással folytatta tevékenységét. Az integráció eredményeként az összlétszám ténylegesen 197 beosztással és munkakörrel csökkent, az új szervezet 825 rendszeresített állománytáblás hellyel kezdte meg müködését.

Az integráció második ütemének nevezhetjük a 2012. január 1. - április 30. közötti szervezési időszakot, amelyet az új szervezeti modell kialakítása érdekében az alábbi fontosabb célfeladatok jellemeztek:

- a katonai hírszerzó és elhárító tevékenység egységes vezetésének kialakítása;

- feladatköri párhuzamosságok megszüntetése;

- a vezetési szintek és a vezető beosztások optimalizálása;

- belső szabályzók felülvizsgálata;

- a múveleti utasítások rendszerének átdolgozása;

- az együttmúködési megállapodások áttekintése, módosítása,

- a gazdasági, személyzeti, műszaki integrálás megvalósítása.

A célok elérése érdekében a két katonai szolgálat összevonását követően azonnal megkezdték a múködési mechanizmusok gyakorlati felülvizsgálatát, valamint az egyes szakterületek müködésének finomhangolását célzó belső ellenőrzéseket. Azonban a változtatásokat igénylő szervezési időszakban is az Nbtv.-ben rögzített szakmai feladatok folyamatos ellátása maradt az elsődleges szempont.

A jogalkotói és vezetői szándéknak megfelelően egy szakmailag eredményesebb, költségvetésének felhasználását tekintve pedig takarékosabb szervezet jött létre, ahol a párhuzamosságok megszüntetésével jobban biztosítható a katonai hírszerző és elhárító tevékenységből származó információk áramlása, továbbá a szakágak tevékenységei kiegészítik egymást.

Az előző mondatban tett állítás alátámasztására érdemes idézni az Állami Számvevőszék 2013. évi ellenőrzésének fő megállapítását: „][A] KNBSZ megalakítása közpénz megtakarítást eredményezett. Az intézkedések takarékosabb gazdálkodást elősegítő hatásai az átalakulás előtti, illetve az átalakulás utáni intézményi teljesítési kiadások és a létszámadatok alapján egyértelműen kimutathatók voltak. A KNBSZ a változatlan volumenú feladatot kevesebb létszámmal, kisebb teljesített kiadással valósította meg, mint jogelődjei." Végső soron a szervezet költségmegtakarítást tudott elérni a mintegy 20\%-os létszámcsökkentés végrehajtásával (elsősorban a múvelettámogató és kiszolgáló területen), amely összességében évi mintegy 1,55 milliárd forintos megtakarítást jelentett. Hosszabb távon további több százmillió forintos megtakarítást feltételezett az a tény is, hogy a két jogelőd szolgálat által használt objektumok közül kevesebbet kellett tovább üzemeltetni.

Az előzőekben leírtakhoz azonban mindenképp szükséges megjegyezni, hogy a bemutatott nemzetbiztonsági szerveket érintő integráció sajátságos formában zajlott le tekintettel arra, hogy nem előzte meg egy olyan átgondolt hatástanulmány

Magyar Köztársaság Katonai Biztonsági Hivatal megszüntető okirata. Hatály: 2011. XII. 30. 
(készültek erre vonatkozó anyagok, de csak „,belső használatra”), amely mögött egy hosszabb időszakot felölelő kutatómunka húzódott volna meg. Így az integrációt bonyolító vezetők folyamatosan szembesültek a megszűnő és átalakuló szervezetek pénzügyi, humán szervezési és szakmai integrációs problémáival, a kialakult anomáliákkal, amelyekre a lehetőségekhez mérten a legjobb válaszokat próbálták megfogalmazni. A kiigazítás folyamatai a közelmúltig megfigyelhetőek voltak a célfeladatok teljes körü teljesítése érdekében.

\section{Az integrált szervezeti modell sajátosságai}

A hivatalos megfogalmazás szerint: a KNBSZ mint Magyarország katonai nemzetbiztonsági szolgálata, ellátja Magyarország nemzetbiztonsági érdekeinek a honvédelmi ágazatban történő érvényesítését. A KNBSZ a kormány - miniszter útján gyakorolt - irányítása alatt álló, az ország egész területére kiterjedő illetékességgel rendelkező, a HM fejezetében az előirányzatok feletti rendelkezési jogosultság szempontjából önállóan múködő és gazdálkodó költségvetési szerv. ${ }^{12}$ A KNBSZ mint központi államigazgatási szerv az Államháztartási Szakfeladatrend alapján a katonai védelem szakágazatba tartozik, alaptevékenysége: katonai nemzetbiztonsági tevékenység. ${ }^{13} \mathrm{~A}$ parlamenti ellenőrzés tekintetében a demokratikus kontrollt továbbra is az Országgyúlés Honvédelmi és Rendészeti valamint a Nemzetbiztonsági Bizottság gyakorolja.

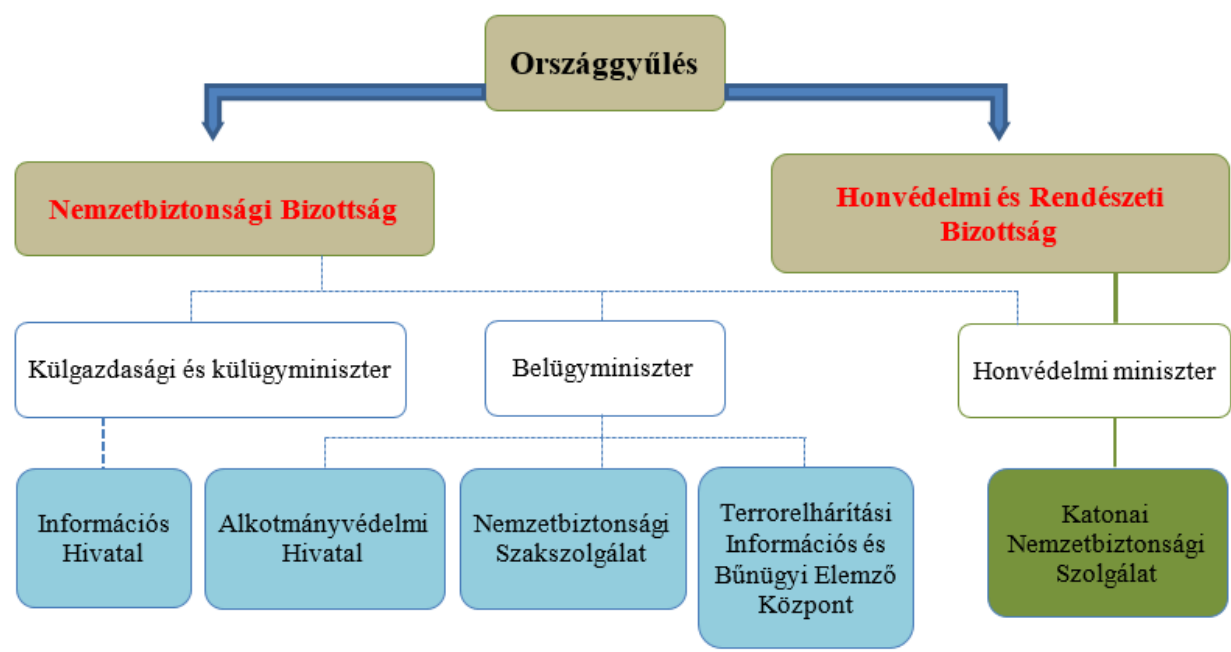

5. ábra

Parlamenti ellenőrzés rendszere

Forrás: a szerző szerkesztése 
Az újonnan létrejött szervezet élén a honvédelemért felelős miniszter irányítása alatt továbbra is a főigazgató áll, akinek feladatát képezi az integrált szervezet egyes elemeinek összehangolása, a szervezeti szintű múködési feltételrendszer megteremtése. Mindennek érdekében a felülvizsgálatot követően folyamatosan átdolgozták a főigazgatói szintű szabályzókat, az együttműködőkkel korábban kötött megállapodásokat, azok tartalmi elemeit. Jelentősen átalakították az ügyeleti és készenléti szolgálatok rendszerét, valamint kialakították az új gazdálkodási és humánszolgálati modelleket. A jogszabályi előírás értelmében elkészítették az új Szervezeti és Működési Szabályzatot, amely a vonatkozó törvény alapján részletezi a KNBSZ rendeltetését és kiegészítő feladatait, valamint a szervezetére, irányítására, vezetésére és működésére vonatkozó alapvető szabályokat. Megjegyzem, hogy a Szervezeti és Múködési Szabályzat az elmúlt években a biztonságpolitikai környezet változásaihoz igazodó újabb feladatok megjelenése, illetve a HM és KNBSZ igényeken nyugvó szervezeti módosítások miatt számtalanszor módosult.

Az integrációt követően a főigazgató irányítása alatt két műveleti főigazgatóhelyettes funkcionált. A két elkülönülő múveleti szakterületen kívül közvetlenül a főigazgatóhoz kötődően (függetlenítve) múködtek a müvelettámogató területekért felelős vezetők, közülük is kiemelten a gazdálkodási (pénzügyi) ellenőrzésére szolgáló egység. Mindez annak biztosítása érdekében, hogy az integráció során elgondolt gazdasági érdekek továbbra se csorbulhassanak. A biztonsági és jogi, a koordinációs és tervezési, a gazdálkodási, a humán és a múszaki szakterületek önállóan jelentettek a főigazgatónak, amely a napi múködés irányításában (és ebben a formában vezetésében is) jelentős energiát kötött le. A vezetés célszerüsége és szakmai irányításának szervezése miatt későbbiekben ez módosult és alacsonyabb vezetői szintekhez lett átsorolva. A szervezetet alapvetően jellemezte, hogy a jogelőd szervezetektől átvett feladatok hatékonyabb és eredményesebb megoldását kellett az új szervezeti berendezkedéssel ellátni.

Egy 2012 szeptemberében a HM vezetése által összehívott értekezlet és egyeztetés döntésének eredményeképpen megszületett a szervezet elhelyezésére vonatkozó végleges elképzelés is. A KNBSZ a Budapest 11. kerületi Bartók Béla úti objektumot feladja, a Schweidel utcai objektumban kialakítandó központtal és a Budakeszi úti szakmai szervezeti elhelyezésekkel kellett tervezni a jövőben. 2019. évre az elképzelés annyiban módosult, hogy a Budakeszi elhelyezési körlet vált a központi objektummá és kezdődött meg a szakmai állománnyal történő feltöltése. 


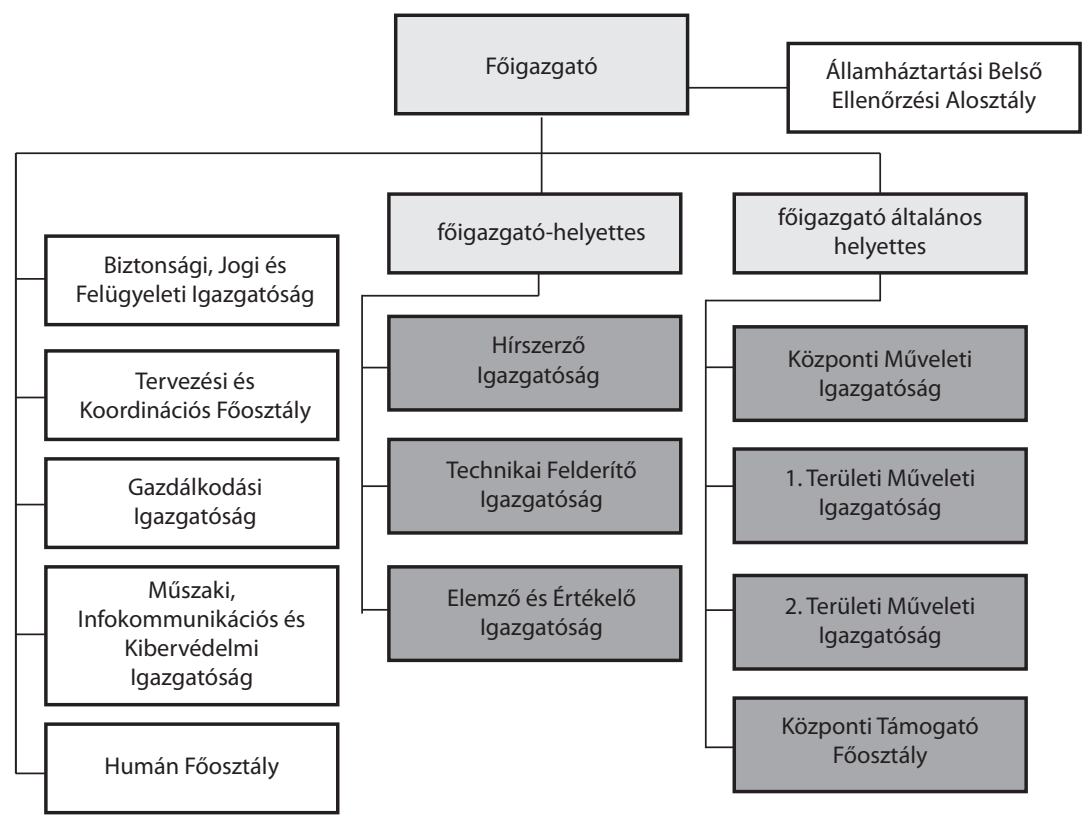

6. ábra

A KNBSZ felépitése 2012. január 1.

Forrás: KENEDLI-KIS-BENEDEK-SZABÓ 2016, 121.

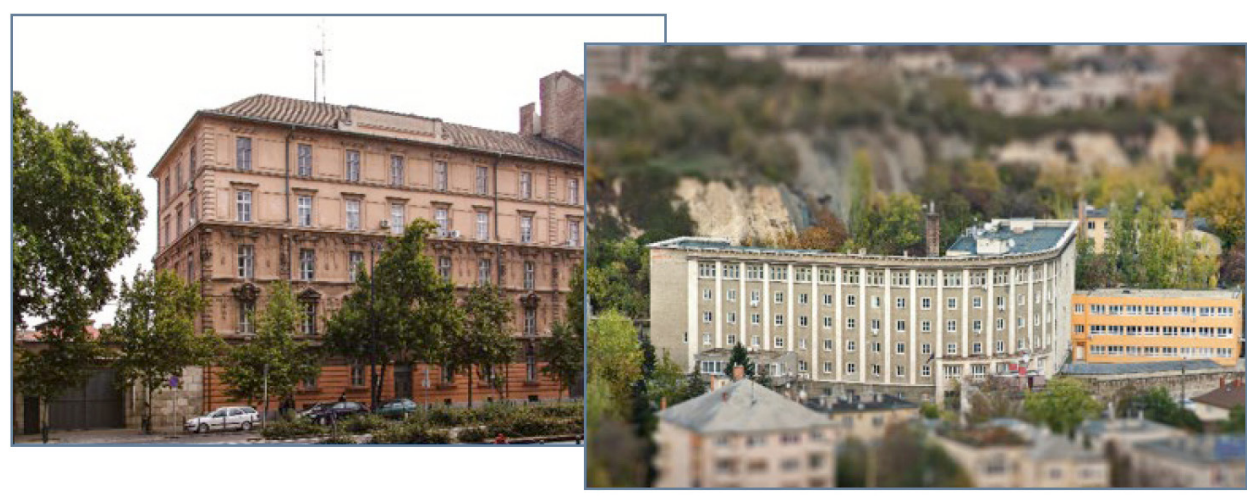

7. ábra

KNBSZ objektumok (Budapest, Bartók Béla út és Schweidel utca)

Forrás: KNBSZ archívum 
A folyamatok mind a mai napig nem záródhattak le, ugyanis a központi objektumból történő elköltözés és a megmaradó elhelyezési körletekben több szakaszban lefolytatásra tervezett felújítási munkálatok rendkívül költségigényesek. Forrásokat a rendelkezésre álló pénzügyi tervezési időszakokban lehet tervezni e célra. 2013 februárjában a KNBSZ előterjesztése alapján a HM felvállalta a költözés miatti átalakítások költségvetési finanszírozását és a miniszter jóváhagyta a beszerzési eljárás megindításához szükséges előirányzatokat. A felújítások és karbantartások elhúzódását feltételezte az a tény, hogy az igényhez képest 50\%-os mértékű támogatás állt a szervezet rendelkezésére. Saját forrásokból csak minimális kiegészítésre nyílt lehetőség, hiszen az induló évben nem változott, a következő két évben 6\%-kal, majd 5\%-kal csökkent a jogelőd szervezetek előirányzatához képest a biztosított forrás nagysága.

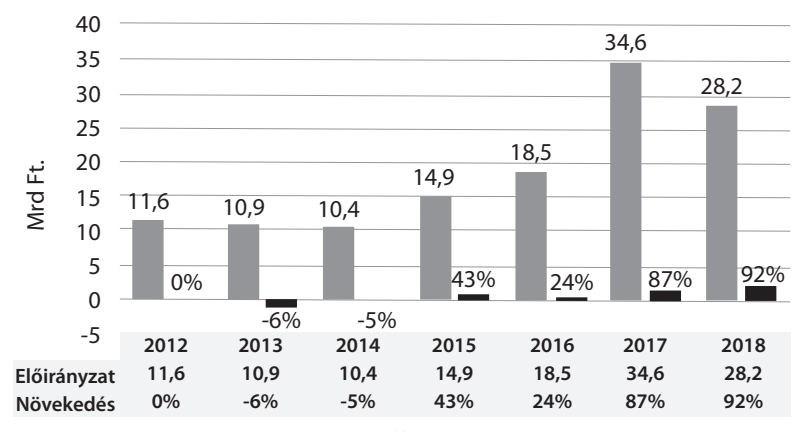

8. ábra

A KNBSZ gazdálkodásának jellemzői 2012-2017

Forrás: KNBSZ archívum

A felsoroltak mellett az elhelyezésre vonatkozó végleges döntést követően (a szervezet a Budakeszi úti objektumba fog költözni) elkezdődött az objektumban a felújítási munka. A feladatok nagyságrendjét szemléltette, hogy 30 ezer m² épület és építmény, 5 km-es belső út és 10 km-es elektromos hálózat, 4 km-es víz- és szennyvízvezeték, 3,6 km kerítés, 4 km-es optikai és 1400 km-es gyengeáramú hálózat karbantartása és fejlesztése kezdődött meg a korábban részletezett, rendelkezésre álló költségvetési forrásokhoz mérten.

Szervezési és humán oldalról a kezdeti éveket a folyamatos korrekciók és racionalizálások jellemezték, amely helyzetre már az induláskor felkészült a vezetés. Érthető és logikus álláspontról beszélünk, hiszen a lebonyolított átszervezéshez fogható változásra korábban nem volt példa. Bár a szigorúan vett összevonást 2012. április 30-ig teljesítette a szervezet, azonban a múködés csiszolása, a feltételrendszerek optimális kialakítása csak a gyakorlati tapasztalatok alapján, folyamatos átalakításokkal valósulhatott meg.

Az összevonás legnagyobb technikai kihívását az informatikai rendszerek folyamatos üzemeltetése jelentette. A szigetszerűen működő, elavult hálózatok, ezek szervereinek és munkaállomásainak összekapcsolása, ezzel párhuzamosan az adatvédelem és a folyamatos üzemképesség fenntartása a meglévő - létszámában csökkentett - állomány 
részére folyamatos kihívást jelentett. Az információs technológiai rendszerek mellett a technikai eszközparkra nézve is jellemző volt, hogy zömében elavult, üzemidejüket letöltött eszközök múködtetése összehangolt munkát és nagy erőfeszítést igényelt, különösen annak fényében, hogy az összevonást követően több vidéki kirendeltség kezdte meg múködését.

Az információs technológiák területén a jogszabályi előírások változása, továbbá az elektronikus információs rendszerek komplexitása, a rendszereken tárolt adatok mennyiségének növekedése és azok minősítési szintje megkövetelte egy tisztán kibervédelmi feladatokat ellátó szervezeti egység megalakítását. Egy a 2012. január 1-jével létrehozott osztállyal ez lehetővé vált, amely más informatikai üzemeltető, fejlesztő szervezeti egységgel együtt közös igazgatóságon belül végezte feladatait. A módosított Nbtv. a jogelőd szervezeteknél hagyományokkal nem rendelkező új feladattal bővítette a KNBSZ nemzetbiztonsági tevékenységi körét: információkat gyüjt a honvédelmi érdeket veszélyeztető kibertevékenységről. ${ }^{14}$ Az új szervezeti egység elsődleges feladata az informatikai rendszereket érő kihívások kezelése, a honvédelmi érdekeket és a nemzetbiztonságot veszélyeztető informatikai támadásokkal szembeni védekezés lett.

Az integráció első évét követő további szervezeti kiigazítások 2013. második félévétől átformálták a KNBSZ struktúráját. A főigazgatói vezetés alatt jól elkülönülő módon megjelent a múveleti területekért összességében, valamint a művelettámogató területért felelős főigazgató-helyettes, illetve ezt követően az elhárító területért felelős főigazgató-helyettes funkciója. A múveleti és múvelettámogató felosztás továbbra is jelen volt, illetve egyértelműen azonosíthatók a főigazgatóhoz kapcsolódó szervezi egységek is. A tervezési és koordinációs szakterülethez csoportosították át a vezetést támogató Törzs Osztály állományát. Jelentősebb változás a múveleti oldalon következett be a kibervédelmi szakterület Rádióelektronikai Felderítő Igazgatóságba történő integrálásával, valamint már 2014. évben a Felderítő Csoportfőnökség mint új szervezeti elem létrehozásával.

A kibervédelmi szakterülettel kapcsolatban a 2014-es évtől miniszteri utasításban is maghatározott feladat a kibertérből származó információszerző képesség és a honvédelmi ágazati informatikai biztonsági eseménykezelő képesség kialakításának igénye. ${ }^{15}$ A KNBSZ-nél megkezdődtek az eseménykezelés rendjére vonatkozó tervezések. Egy évvel később a kormány a honvédelmi célú elektronikus információs rendszereket érintő biztonsági események és fenyegetések ágazati kezelésére a HM tárcán belül a KNBSZ-t jelölte ki a feladat végrehajtására, továbbá számára tájékoztatási és tudatosítási feladatkört is rótt. ${ }^{16}$ Ezt követően 2016. február 25-től „a Kormány a honvédelmi célú elektronikus információs rendszerek biztonságának felügyeletét ellátó hatóságként a Katonai Nemzetbiztonsági Szolgálat főigazgatóját jelölte ki". ${ }^{17}$ A jogszabályi követelmények teljesítésére 2016. március 1-jével megalakult a Kibervédelmi Központ, amely három osztályával képes az eseménykezeléssel, a hatósági 
feladatokkal, a sérülékenységvizsgálattal és elemzéssel kapcsolatos tevékenységek elvégzésére.

A honvédelmi miniszter 2014. május 31-i hatállyal, jogutódlással megszüntette a HVK Felderítő Csoportfőnökséget, ${ }^{18}$ amely állományával és feladatrendszerével - önálló szervezeti elemként - integrálódott a KNBSZ szervezetébe. A szervezeti átalakítás elsődleges célja a Katonai Egységes Felderítő Rendszer szervezeti kereteinek megteremtése volt. Mindez annak érdekében zajlott, hogy az MH felderítő rendszere megfeleljen napjaink kihívásainak, képes legyen a parancsnoki döntéshozatalhoz, valamint az MH műveleteinek vezetéséhez szükséges felderítő támogatás biztosítására, egyúttal megfeleljen a szövetségi követelményeknek és képes legyen a szövetségi felderítő rendszerhez való kapcsolódásra.

A KNBSZ szervezetében 2014. június 1-jei hatállyal megalakított Felderítő Csoportfőnökség a megszüntetett HVK Felderítő Csoportfőnökség feladatait vette át. Ezzel a szervezeti átalakítással az MH felderítő képességei egységes szakmai vezetés alá kerültek, hiszen a KNBSZ főigazgatója a Felderítő Csoportfőnökségen keresztül szakmai felügyeletet gyakorol az MH felderítő képességei felett; amely lehetővé tette a centralizált irányítás és decentralizált végrehajtás elve szerinti múködést. Az integráció eredményeképpen megvalósulhatott a katonai hírszerzés és felderítés egységes szakmai irányítása, a meglévő felderítő erők és eszközök hatékonyabb felhasználása, fejlesztése, a felhasználók információkkal történő ellátásának minőségi fejlesztése, valamint a béketámogató múveletekben részt vevő magyar kontingensek biztonságának növelése. A feladatracionalizálás további hozadéka, hogy katonai felderítés béke és különleges jogrendben is közel azonos rendben múködik. Az MH felderítő és elektronikai szakterületének menedzselése hatékonyabbá válhatott, továbbá lehetőség nyílt új felderítési ágak kialakítására, fejlesztésére (IMINT képesség, földi mozgócél felderítő lokátorképesség).

A Felderítő Csoportfőnökség jelenleg is közvetlenül hozzájut a müvelettervezés és -vezetés támogatásához szükséges információkhoz - ezzel kisebb reagálási idővel képes kielégíteni a parancsnok elsődleges felderítési igényeit.

A Bécsben, 1961. április 18-án aláírt diplomáciai kapcsolatokról szóló nemzetközi szerződés alapján, ${ }^{19}$ továbbá az Nbtv. vonatkozó rendelkezései és a véderő-, katonai és légügyi attaséhivatalok irányításáról, vezetéséről és ellenőrzéséről, valamint a katonai attasékkal való kapcsolattartásról szóló HM utasítás ${ }^{20}$ szerint, katonadiplomáciai területen Algírtól Washingtonig számos országban működnek akkreditált véderő-, katonai és légügyi attaséhivatalok.

Magyarország jelenleg 19 országban müködtet véderőattasé-hivatalt, katonadiplomatáink összesen 56 országba vannak akkreditálva. ${ }^{21}$ Az attaséhivatalokat a honvédelmi miniszter - a HM védelempolitikai helyettes államtitkár és a KNBSZ főigazgatója útján - irányítja és felügyeli. A katonadiplomáciai feladatok jelenleg is részben átakkreditálással részben budapesti állomáshelyü, regionális katonai

40/2014. (VI. 5.) HM utasítás.

Magyarországon kihirdette a diplomáciai kapcsolatokról Bécsben, 1961. április 18-án aláírt nemzetközi szerződés kihirdetéséről szóló 1965. évi 22. törvényerejű rendeletet.

53/2007. (HK 12) HM utasítás.

ÁRVAI-GYARAKI 2018, 168. 
KEnEDLI TAMÁs: A Katonai Nemzetbiztonsági Szolgálat szakmai fejlődésének...

attasék alkalmazásával teljesülnek. Az attaséhivatali rendszer folyamatosan változik, átalakulását befolyásolja a szövetségi rendszer érdekviszonyai; Magyarország biztonsági és katonapolitikai érdekei; a magyar nemzetközi szerepvállalás helye és ideje; a magyar haditechnikai és hadigazdasági érdekek; az adott ország világ- és katonapolitikai súlya; a válságkörzetek helyszínei; a (katona)diplomáciai paritás, valamint gazdasági és hadiipari megfontolások. Természetesen mindezek súlyozása az aktuális kihívásokhoz történő megfelelés érdekében a kor követelményeihez igazítva, a rendelkezésre álló anyagi erőforrások keretei között történik.

A súlyozásra példaként említem, hogy 2013-tól - pénzügyi okok miatt - szünetelteti múködését az athéni, a zágrábi és a tiranai képviselet, aminek következtében a korábbi két regionális attasé poszt mellett (Dél-Európa-Budapest: Athén, Nicosia, Szófia; Közép Európa-Budapest: Bécs, Pozsony, Prága) megkezdte múködését egy harmadik (Nyugat-Balkán-Budapest: Ljubljana, Tirana, Zágráb) állomáshely, úgy, hogy a korábbi akkreditálások természetesen a helyzethez igazodtak. 2016-ban a zágrábi, majd 2017-ben a gazdasági lehetőségekre és szakmai igényekre - visegrádi négyek fontosságát hangsúlyozva - tekintettel a KNBSZ újra nyitotta a prágai és pozsonyi attaséhivatalokat, illetve 2018. évben megnyitotta a szkopjei és bécsi székhelyü véderő, katonai és légügyi attassé hivatalait is.

Az attaséhivatali rendszerben dolgozók tevékenységükkel jelenleg is képviselik a $\mathrm{HM}$, az $\mathrm{MH}$ parancsnoka érdekeit, előmozdítják a kétoldalú együttmúködési feladatokat, védelmezik a fogadó államban lévő katonaszemélyek érdekeit, képviselik a KNBSZ-t a fogadó állam partnerszolgálatainál, részt vesznek a hivatalos látogatások előkészítésében és azok lebonyolításában. Mindezek mellett kapcsolatot tartanak a fogadó állam katonai szervezeteivel, különféle egyezmények, megállapodások előkészítésének részesei, továbbá elősegítik a hadiipari együttműködést. Sajátságos tevékenységi rendszerükben részesei - országoktól függően - a hadisírgondozás rendszerének.

Az elhárítás szakterületén, a hagyományos müveleti képességek mellett felértékelődött a személy és iparbiztonsági ellenőrzések feladatrendszere. A hatáskörbe tartozó személyek és gazdálkodó szervezetek nemzetbiztonsági és cégellenőrzése, valamint a speciális beszerzésekkel összefüggő ellenőrzések esetszáma növekedést mutatott, ami miatt folyamatos fejlesztés van jelen.

Habár a szervezeti struktúrában külön jelenik meg, ugyanakkor a hírszerző és elhárító szakágaknál hagyományosan meglévő elemző és értékelő szakterület munkájának egymásrautaltsága növekedett, az együttmúködés kiforrottabbá vált. A kooperáció kiterjedt valamennyi szakterületre, továbbá azon objektumokra, szervezetekre és cégekre, amelyek védelme és ellenőrzése a KNBSZ hatáskörébe tartozik. Ezen túlmenően témaspecifikusan, a speciális képességüknek megfelelő munkamegosztásban tevékenykedve is szolgáltatnak hasznos információkat a megrendelők részére. Mindehhez folyamatosan megújuló technológiai háttér alkalmazása társul.

2017. július 1-től megalakult a HM Védelmi Technológiai Kutató Központ. A szervezeti egység fő feladata a honvédelmi tárca haditechnikai irányú kutatás-fejlesztési és technológiai innovációs tevékenységének stratégiai szintű felügyelete, 
a kutatás-fejlesztési feladatok fő irányainak meghatározása, továbbá a Zrínyi 2026 Honvédelmi és Haderőfejlesztési Programmal összefüggő hadiipari kutatás-fejlesztési feladatok végrehajtása. Mindennek kapcsán múködési területén illetékes a nemzetközi és hazai haditechnikai és hadiipari együttmüködési programok szervezésében és lebonyolításában, valamint nemzeti képviselet biztosításában aNATO-, EU-szervezetekben, illetve a V4 közösségen belül. A kutatóközpont 2019. év január 1-jétől a Magyar Honvédség parancsnokának közvetlen szolgálati alárendeltségében, Modernizációs Intézet néven végzi tovább feladatait.

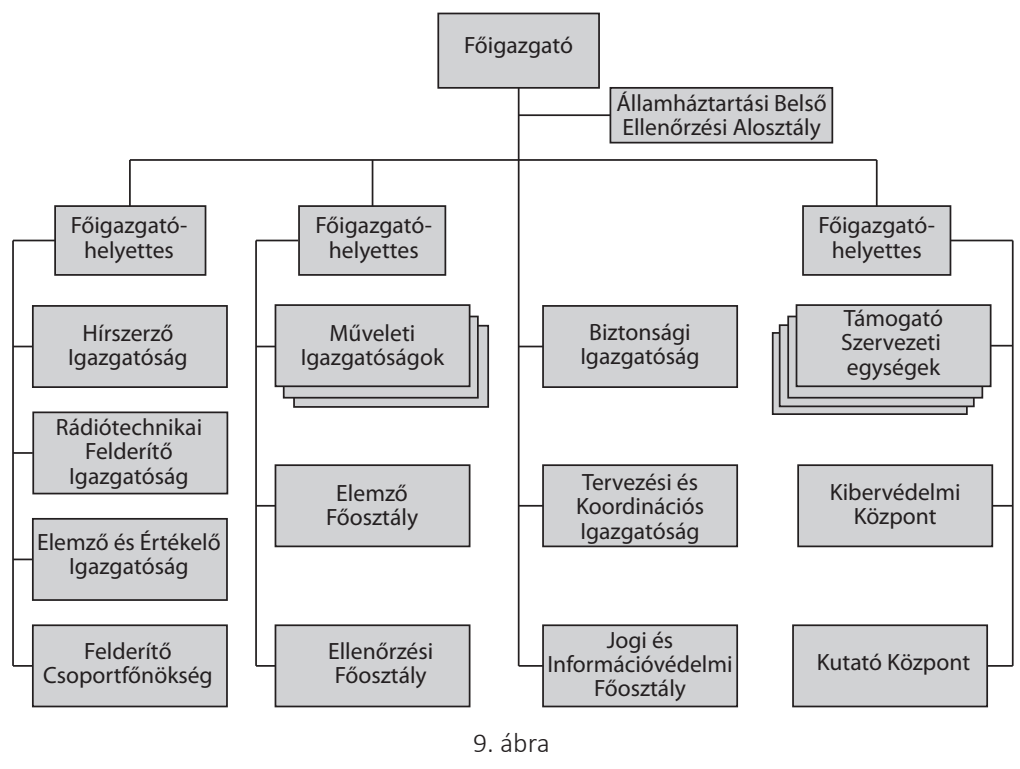

A KNBSZ felépítése 2018. január 1.

A szervezeti finomhangolások időszakát követően egy újabb, jelenős személyügyi változás következett be 2018. június 1-jén, amikor a KNBSZ főigazgatóját a Nemzeti Információs Államtitkárság (a továbbiakban: NIÁT) mint új kormányszerv élére kinevezték.

Feladatait, s így a KNBSZ irányítását Dr. Béres János vezérőrnagy vette át, aki korábban több mint öt évig töltötte be a főigazgató-helyettesi posztot. Azt megelőzően 1993-tól a KFH-nál mint jogelőd szervezetnél dolgozott, több alkalommal teljesített külszolgálatot (Romániában, Irakban, az Egyesült Államokban, Kínában), majd a KNBSZ hírszerző igazgatóhelyetteseként tevékenykedett egészen a főigazgatóhelyettesi pozícióba lépéséig. Kijelenthetjük, hogy az új főigazgató mind a hírszerzés, mind az elhárítás területét is felügyelte az elmúlt években, így ismeri azoknak a legfontosabb összetevőit, továbbá részt vett a különböző kultúrával rendelkező katonai nemzetbiztonsági szolgálatok egységes, jól működő szolgálattá kovácsolásában. 


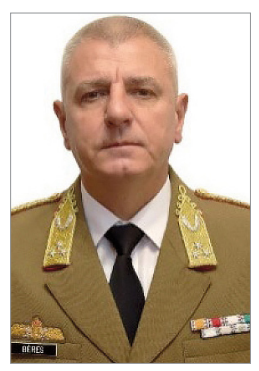

10. ábra

Dr. Béres János altábornagy, föigazgató, 2018-

Forrás: BÉRES et al. 2018, 419

A főigazgatóváltást követően továbbra is cél maradt az egyes szakterületek kor színvonalának megfelelő fejlesztése, különös tekintettel a kibervédelmi képességek, a technikai információszerzés és a hadászati felderítő képesség tekintetében. A katonadiplomácia területén a KNBSZ vezetésének célja egy olyan külképviseleti rendszer múködtetése, amely legoptimálisabban képes kiszolgálni a szakmai érdekeket és képes a várható kockázatok előrejelzésére. Az elemző-értékelő szaktevékenység technológiai hátterének folyamatos megújítása hírszerző és elhárító területen ugyancsak elengedhetetlen manapság. A katonai életpályamodell szervezetre történő alkalmazása, fejlesztése mellett a múvelettámogató szakmai szervezeti egységek vonatkozásában több olyan változtatás történik, amelyek várhatóan a múveleti munkát végző szervezeti egységek tevékenységének hathatósabb támogatását eredményezik.

A munkatársak szakmai fejlődése érdekében több olyan folyamat lezajlott, illetve jelenleg is tart, amelyek előnyösen befolyásolják tevékenységünket, szakmai képességeink fejlesztését. Ezek közül legnagyobb léptékű a Nemzetbiztonsági Intézet (a továbbiakban: intézet) 2012. február 3-ai megalapítása volt a Nemzeti Közszolgálati Egyetemen. Az intézet a Katonai Nemzetbiztonsági Tanszékben gyökerezik, amely a korábbi Zrínyi Miklós Nemzetvédelmi Egyetemen belül, a kétezres évek elejétől folytatta a katonai nemzetbiztonsági szakemberek egyetemi szintú képzését. Az intézet a korábbi Katonai Nemzetbiztonsági Tanszék bázisán alakulhatott meg a fenti időpontban. A nemzetbiztonsági képzés rendszere a létrehozás óta több fejlesztési fázison ment keresztül a képzés irányultsága (integritása), tematikája, tananyaga, tekintetében egyaránt. Mindezek mellett a felsőoktatási akkreditációs és minőségbiztosítási feltételeknek is megfelel. A nemzetbiztonsági tanszékek specializációi illeszkednek a fenntartó minisztériumok (Belügyminisztérium és Honvédelmi Minisztérium) követelményeihez és a nemzetbiztonsági szervek igényeihez. A nemzetbiztonsági képzés területén, erősítve a polgári és katonai jellegú képzés értékrendszerét 2018 augusztusától az NKE Rendészettudományi, valamint a Hadtudományi és Honvédtisztképző Karok gondozzák.

Az intézet sokszínú képzési kínálatából mindenképp szükséges megemlíteni a korábbi Vezérkari Tanfolyam mintájára 2016-tól bevezetett Nemzetbiztonsági Felsővezetői Tanfolyamot, amit levelező képzési formában, másfél éves időtartamban a KNBSZ-szel közösen szervez és bonyolít le. Az elmúlt években, az oktatott tantárgyakhoz számtalan jegyzet elkészítésében múködtek közre kollégáink és oktatóként 
segítették a tananyag elsajátítását. Rendszeresen közreműködtek hazai és nemzetközi konferenciákon, szakmai workshopokon. További fontos minőségjavító tényező volt az állomány felkészítése szempontjából, a KNBSZ belső tanfolyami rendszerének fejlesztéscentrikus fenntartása, újabb elemekkel történő bővítése.

Ugyancsak támogatóan hatott a folyamatosan megújuló szervezetre a kutatásfejlesztési folyamatok célirányos megújítása. 2016-ban a KNBSZ alapító okiratába is belekerült a fenti tevékenységi kör mint „védelmi tevékenységgel kapcsolatos alkalmazott kutatás és fejlesztés". ${ }^{22}$ Mindez azt jelenti a szervezet szempontjából, hogy költségvetési kutatóhelyként alapkutatást, alkalmazott kutatást és kísérleti fejlesztést folytat. A kutatások elsősorban az Nbtv.-ben meghatározott hírszerző, elhárító, felderítő, védelmi és ellenőrzési feladatok végzése, nyílt és titkos információgyújtés témában, Magyarország nemzetbiztonsági érdekei érvényesítésének elősegítése érdekében szerveződnek. A KNBSZ-nél végrehajtói szinten folyó kutatás-fejlesztés célja elsősorban az ország védelmi képességének és biztonsági helyzetének javítása, valamint a szakmai munka támogatása. Ennek keretében hozzájárul a hazai felsőoktatás és a doktori képzések színvonalának növeléséhez, illetve megalapozza a belső szakmai tanfolyamok minőségét. A kutató-fejlesztő tevékenység sikeres folytatása érdekében annak szervezeti hátterét meg kellett teremteni és szervezetbe ágyazását is elkellett végezni, illetve a szabályozás oldaláról megalapozni.

A KNBSZ Tudományos Tanácsa az a „virtuális” szervezeti forma, amely a végrehajtói szinten folyó kutatás-fejlesztési tevékenységet koordinálja, felügyeli, irányítja, valamint közvetlenül végzi. Tevékenysége mellett jöhettek létre olyan konferenciák, mint a "Terrorizmus finanszírozása elleni fellépés lehetőségei” (2016), vagy „Az elemzés 21. századi dimenziói” (2018) és a "70 éves az Észak-atlanti Szerződés Szervezete” (2019) című tudományos-szakmai rendezvények, továbbá a „100 éves a magyar katonai hírszerzés és elhárítás" (2018) című szakmatörténeti konferencia. Az elmúlt években különféle a nagyközönség számára is érdekességgel bíró témákkal megjelentünk a „Kutatók éjszakája” rendezvénysorozat helyszínein is.

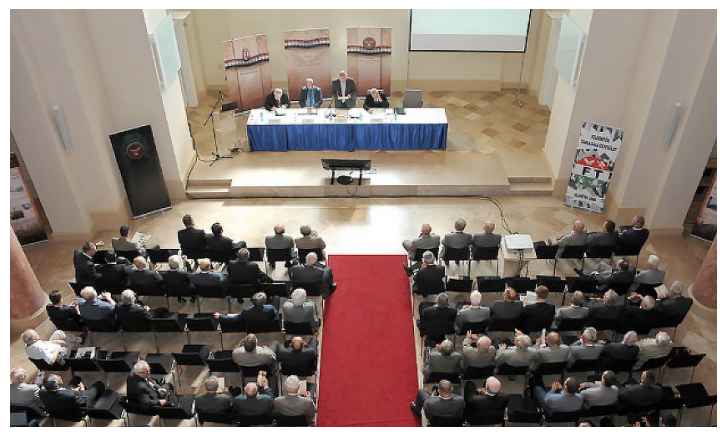

11. ábra

100 éves a magyar katonai hírszerzés és elhárítás (konferencia)

Forrás: https://honvedelem.hu/cikk/katonai-nemzetbiztonsag-mult-jelen-jovo/ (A letöltés dátuma: 2019. 12. 01.)

$22 \quad$ Alapító okirat - módosításokkal egységes szerkezetbe foglalva (2016). 
KEnEDLI TAMÁs: A Katonai Nemzetbiztonsági Szolgálat szakmai fejlődésének...

Közvetlenül támogatjuk munkatársaink tudományos kutatói tevékenységét, a tudományos doktori képzéseken történő részvételét, a szakmai könyvek elkészítésének folyamatát. A KNBSZ jelenleg is több tudományos-szakmai szemlét jelentet meg, amelyek a civil szektor számára is elérhetők. Ezek a tevékenységek együttesen abba az irányba hatnak, hogy a szervezeten túlmutató méretekben, együttmüködésben egyetemekkel, kutatóhelyekkel és piaci szereplőkkel képesek vagyunk nagyobb kutatási projekt keretében ismereteink bővítésére, végső soron a szervezet fejlesztésére.

\section{A szakmai és szervezetmodernizációs feladatok}

A KNBSZ múködésének lényeges szabályait jelenleg is az Nbtv. tartalmazza. Éves tevékenységét alapvetően a törvény szerinti miniszteri feladatszabás, illetve utasítás határozza meg, amelyek alapján évenként elkészíti az információszerző és biztonságvédelmi feladattervét. A törvényben, valamint a fenti dokumentumokban meghatározott fő feladatok végrehajtására a főigazgató intézkedésekben határozza meg a feladatteljesítés szakmai feltételeit, módszereit, erőit, eszközeit. A már elfogadott éves tervektől eltérően, akár a kialakult külföldi és belföldi helyzetnek megfelelően, akár a NATO, az EU vagy az MH parancsnoka irányából érkező hírigények kielégítése céljából újabb feladatok meghatározására is sor kerülhet. További 2018. július 1-jétől megjelenő feladattípus a kormányzat hírigényét kiszolgáló NIÁT részére a kormányzati döntésekhez kapcsolódó, külföldre vonatkozó, illetve külföldi eredetú információk szolgáltatása a hírszerzési tevékenységgel összefüggő kormányzati feladatok koordinációjának megkönnyítése érdekében.

A KNBSZ az Nbtv.-ben meghatározott - különösen hírszerző, elhárító, felderítő, védelmi és ellenőrzési - feladatok végzésével, a nyílt és a titkos információgyűjtés eszközrendszerével, működési területén elősegíti Magyarország nemzetbiztonsági érdekeinek érvényesítését, ezáltal közreműködik az ország függetlenségének és törvényes rendjének védelmében.

A szolgálat fő erőkifejtését a biztonságpolitika katonai elemeire, a katonapolitikára, a hadiiparra és a katonai információkra összpontosítja. Értékeli hazánk mindenkori biztonsági helyzetét, előre jelzi az ország elleni katonai fenyegetést, elemzi a Magyarország közvetlen környezetében elhelyezkedő katonai erőket, felfedi szándékaikat. Kiemelt figyelmet fordít a térségünkben formálódó válságok előrejelzésére, illetve a már kialakult válságkörzetek eseményeire. A többi hazai nemzetbiztonsági szolgálatokkal együttműködve részt vesz az ország biztonságát veszélyeztető egyéb tényezők - terrorizmus, szervezett bűnözés, illegális fegyverkereskedelem, nemzetközileg ellenőrzött termékek és technológiák jogellenes forgalma stb. - felderítésében, információt gyűjt például a honvédelmi érdeket sértő kibertevékenységről. Továbbá ellátja a HM és az MH objektumainak, állományának biztonsági védelmét. Speciális képessége révén a hadászati rádióelektronikai felderítőrendszer üzemeltetésével információkat szolgáltat a Magyar Honvédség múveleti területen lévő alakulatait és azok állományát veszélyeztető törekvésekről és tevékenységekről, valamint az országvédelmi feladatok vonatkozásában információkat biztosít a Honvéd Vezérkar hadászati-hadmúveleti tervező munkájához. A szervezet jellegéből fakadóan, a beszerzett információkra 
és feltárt összefüggésekre tekintettel, Magyarország állami és katonai vezetőinek differenciált tájékoztatását ugyancsak ellátja.

A KNBSZ illetékességébe tartoznak:

- a HM és az MH parancsnoksága, illetve azok szervei, szervezetei, intézményei, csapatai és objektumai;

- a HM hivatalai, háttérintézményei és gazdasági társaságai;

- a miniszter vagy korábban a HVKF által alapított illetve irányított, továbbá a HM és az MH érdekében folytatott hadiipari kutatásban, fejlesztésben, gyártásban, kereskedelemben, valamint a cégellenőrzés hatálya alá tartozó más tevékenységben részt vevő gazdálkodó szervezetek;

- a KNBSZ-nél valamennyi jogviszonyba tartozó bármely, továbbá az előzőekben szereplő szervezeteknél szolgálatot teljesítő hivatásos, köztisztviselői, kormánytisztviselői, közalkalmazotti jogviszonyban, vagy egyéb munkaviszonyban állók, a tartalékos állomány, illetve a HM-mel, az MH-val jogviszonyban állók, a közjogi szervezetszabályozó eszközökben, valamint a társ nemzetbiztonsági szolgálatokkal folytatott együttmúködés keretében vagy nemzetközi egyezményekben meghatározott személyek.

A KNBSZ feladatainak ellátása szempontjából meghatározó jelentőségű a szövetséges, valamint azon országok katonai hírszerzó és elhárító szerveivel fenntartott kapcsolat, amelyekkel Magyarország közösen vesz részt nemzetközi missziókban. Ezen alkalmakkor a missziókban szolgáló valamennyi magyar katona védelmét ellátják.

A szolgálat több mint negyven ország, több mint ötven szolgálatával fennálló kapcsolatrendszerében továbbra is a kölcsönös előnyökön alapuló, nemzeti érdekeket és szövetségi elkötelezettséget egyaránt figyelembe vevő együttműködés a cél. A KNBSZ kétoldalú partnerszolgálati együttmúködés keretében eredményes múveleti együttműködést folytat a világ vezető titkosszolgálataival.

A KNBSZ aktívan részt vesz a NATO stratégiai szintű hírszerzési dokumentumainak kidolgozásában, a hírszerzési struktúra kialakításában. A multilaterális hírszerzési és elhárítási együttműködés fontos része lett a prioritást képező, döntés-előkészítő és döntéshozó bizottságok, a terrorizmussal, elemzéssel, egyéb biztonsági kockázatot jelentő területek értékelésével foglalkozó összejöveteleken történő aktív részvétel.

A NATO-vállalásoknak megfelelően, a nemzeti, nemzetközi és a honvédelmi ágazat belső elektronikus információbiztonsági eseménykezeléssel összefüggő folyamatos kapcsolattartás elengedhetetlen napjainkban. Az elektronikus információbiztonságot súlyosan veszélyeztető események folyamatos felügyelete érdekében a honvédelmi ágazat elektronikus információbiztonsági eseménykezelő központja tesz aktív lépéseket.

Az elmúlt években Magyarországon tapasztalható gazdasági fejlődés és foglalkoztatás növekedés okán a honvédelmi ágazatban is szükségessé vált egy újfajta megközelítésű, a munkatársak megtartását célzó, a toborzást elősegítő életpályamodell bevezetése. A KNBSZ vonatkozásában is felértékelődött a kiszámíthatóság és tervezhetőség igénye a szakmai állomány megtartása tekintetében, ezért a 2018-ban jelentős illetményfejlesztés végrehajtása valósult meg. Mindehhez társul a munkafeltételek és munkakörnyezet javítása, az eszközpark folyamatos megújítása. A közelmúltban csaknem teljes egészében megújult a gépjárműpark, a legfontosabb 
elhelyezési objektumainkat részben vagy egészében felújítottuk a kiszolgáló helyiségekkel együtt. A kor színvonalának megfelelő legfontosabb informatikai fejlesztéseket is elvégeztük, amelynek részeként megújulhatott az informatikai gerinchálózat, a szerverháttér, az ezek kiszolgálását végző erősáramú ellátás, valamint a külföldön dolgozó attasé állomány eszközháttere is. Természetesen szem előtt tartva a minősített adat védelméről szóló jogszabály²3 rendelkezéseit, különös tekintettel a fizikai biztonságra vonatkozó követelményeket. A modernizáció részeként lezajlottak speciális szaktechnikai beszerzések, továbbá a Környezeti és Energiahatékonysági Operatív Program forrásának köszönhetően az épületek energetikai és fütés rendszere is korszerüsödött, illetve kiegészült modern fotovoltaikus eszközökkel.

\section{Összegzés}

Úgy gondolom az előző oldalakat olvasva minden érdeklődő számára világossá vált, hogy a hírszerző és elhárító feladatokat egységes szervezetbe foglaló KNBSZ esetében igazolható az integráció során kitűzött célok sikeres megvalósítása. A jelen korunk elvárásaihoz igazodó szakmai irányítás és vezetés előnyei folyamatosan tapasztalhatók, amelyeket az eredmények támasztanak alá és tesznek hitelessé. Mindezek mellett a szervezet életének elengedhetetlen részévé vált a múvelettámogatás hatékony, egységes elvek szerinti átalakítása, az új kihívásokhoz igazítása. Mindez a mai napig komoly szervezeti, múködési, szervezési és együttmúködési feladatok elvégzését jelenti. A biztonsági környezetben bekövetkezett változások leképezése a jogszabályokban, végrehajtási utasításokban, majd a szervezet mint jogalkalmazó szintjén a feladatok elvégzése tekintetében ugyancsak időigényes, többszereplős feladat. Az ennek történő folyamatos megfelelési igény eredményeként jöhetett létre egy megújult múveleti és ezt kiszolgáló múvelettámogatási rendszer. Azonban nem csak szervezeti és módszertani megújulásra volt szükség, a résztvevők szemléletét is át kellett alakítani, amely során a támogatás jellegének, a kiszolgálói munka helyének meghatározása alapelemnek számított. Az igények pontos megértése mellett az előrelátás fontossága kiemelt jelentőséggel bírt. A múvelettámogatás szempontjából a „háttérben” végzett munka nem másodlagosságot jelent, hanem egy olyan kiszolgálási tevékenységet, ahol a szakma által meghatározott feltételek lehetőség szerint maximálisan rendelkezésre állnak.

A KNBSZ múveleti és múvelettámogató szakterületeinek a jövőben is illeszkedni szükséges a napjaink kihívásaiból fakadó új feladatokhoz, amelyek kapcsán a partnerkapcsolatok mellett, az erőforrások biztosítása, a szakszerűség, a gyors reagáló képesség, a folytonosság biztosítása is nélkülözhetetlen lesz. 


\section{Felhasznált irodalom}

ÁRVAI Zoltán - GYARAKI Károly (2018): 100 éves az önálló magyar katonai felderítés, hírszerzés és elhárítás. Budapest, Zrínyi Kiadó.

BÉRES János - BÖRCsÖK András - MISKOLCZI József - ORAVECZ Gábor- SZASZÁk János szerk. (2018): Válogatás a Magyar Katonai Felderités és hírszerzés történetéből. Budapest, Katonai Nemzetbiztonsági Szolgálat.

DEZső Sándor - KENEDLI Tamás (2018): A KNBSZ 2012-2018 közötti hatéves múködésének összegzett tapasztalatai. Felderítő Szemle, 17. évf. 2. sz. 151-164.

JAGADICS Péter - RAJOS Sándor - SIMON László - SzABó Károly (2018): A magyar katonai elhárítás története 1918-2018. Budapest, Univerzum Könyvek.

Katonai Nemzetbiztonsági Szolgálat Alapító Okirata (2011). Hivatalos Értesítő, 63. sz. KENEDLI Tamás - KIS-BENEDEK József - SzABÓ Károly (2016): A katonai felderítés és elhárítás evolúciója, szervezete és feladatkörei. In FARKAS Ádám - KÁDÁR Pál szerk.: Magyarország katonai védelmének közjogi alapjai. Budapest, HM Zrínyi Térképészeti és Kommunikációs Szolgáltató Közhasznú Nonprofit Kft. 117-126.

Magyar Köztársaság Katonai Biztonsági Hivatal megszüntető okirata (2011). Hivatalos Értesítő, 63. sz.

\section{Internetes forrás}

https://honvedelem.hu/cikk/katonai-nemzetbiztonsag-mult-jelen-jovo/ (A letöltés dátuma: 2019. 12. 01.)

\section{Jogforrások}

116/2011. (X. 21.) HM utasítás a katonai nemzetbiztonsági szolgálatok szervezeti és létszám-racionalizálásának egyes feladatairól

128/2011. (XII. 2.) HM utasítás a katonai nemzetbiztonsági szolgálatok összevonásával kapcsolatos egyes feladatokról

185/2015. (VII. 13.) Korm. rendelet a kormányzati eseménykezelő központ és az eseménykezelő központok feladat- és hatásköréről, valamint a biztonsági események kezelésének, a biztonsági események müszaki vizsgálatának és a sérülékenységvizsgálat lefolytatásának szabályairól

187/2015. (VII. 13.) Korm. rendelet az elektronikus információs rendszerek biztonsági felügyeletét ellátó hatóságok, valamint az információbiztonsági felügyelő feladat- és hatásköréről, továbbá a zárt célú elektronikus információs rendszerek meghatározásáról

1965. évi 22. törvényerejü rendelet a diplomáciai kapcsolatokról Bécsben, 1961. április 18-án aláírt nemzetközi szerződés kihirdetéséről

1990. évi X. törvény a különleges titkosszolgálati eszközök és módszerek engedélyezésének átmeneti szabályozásáról

1995. évi CXXV. törvény a nemzetbiztonsági szolgálatokról 
2009. évi CLV. törvény a minősített adat védelméről

2011. évi CLXXI. törvény a nemzetbiztonsági szolgálatokról szóló 1995. évi CXXV. törvény katonai nemzetbiztonsági szolgálatok összevonásával kapcsolatos módosításáról, valamint az azzal összefüggő további törvénymódosításokról

26/1990. (II. 14.) Minisztertanácsi rendelet a nemzetbiztonsági feladatok ellátásának átmeneti szabályozásáról

3039/1990 számú Minisztertanácsi határozat a nemzetbiztonsági szolgálatok létrehozásáról és működési feltételeiről

40/2014. (VI. 5.) HM utasítás a Honvéd Vezérkar szervezeti korrekciójával és a Magyar Honvédség kiképzési és doktrinális feladatokat ellátó központi szervezetének megalakításával összefüggő feladatokról szóló 8/2014. (II. 12.) HM utasítás módosításáról

53/2007. (HK 12.) HM utasítás a véderő-, katonai és légügyi attaséhivatalok irányításáról, vezetéséről és ellenőrzéséről, valamint a katonai attasékkal való kapcsolattartásról

68/2013. (XII. 29.) NGM rendelet a kormányzati funkciók, államháztartási szakfeladatok és szakágazatok osztályozási rendjéről

8/2014. (II. 12.) HM utasítás a Honvéd Vezérkar szervezeti korrekciójával és a Magyar Honvédség kiképzési és doktrinális feladatokat ellátó központi szervezetének megalakításával összefüggő feladatokról

85/2014. (XII. 23.) HM utasítás a honvédelmi szervezetek 2015. évi fő célkitűzéseinek és fő feladatainak, valamint a 2016-2017. évi tevékenysége fő irányainak meghatározásáról

Alapító okirat - módosításokkal egységes szerkezetbe foglalva (2016. január 31.) Okirat száma: 25-2/2016.

T/4816. számú törvényjavaslat a nemzetbiztonsági szolgálatokról szóló 1995. évi CXXV. törvény katonai nemzetbiztonsági szolgálatok összevonásával kapcsolatos módosításáról, valamint az azzal összefüggő további törvénymódosításokról. Budapest, 2011. október. Elérhető: www.parlament.hu/irom39/04816/04816.pdf (A letöltés dátuma: 2019. 12. 01.) 